\title{
World Investment Report 2020: International production beyond the pandemic
}

\author{
United Nations Conference on Trade and Development, \\ Geneva and New York, 2020, 247 pp. \\ ISBN: 978-9211129854
}

\author{
Axèle Giroud ${ }^{1}$ and \\ Inge Ivarsson ${ }^{2}$
}

\footnotetext{
${ }^{1}$ Alliance Manchester Business School, University of Manchester, Manchester, UK; ${ }^{2}$ School of Business, Economics, and Law, University of Gothenburg, Gothenburg, Sweden

Correspondence:

A Giroud, Alliance Manchester Business School, University of Manchester,

Manchester, UK

e-mail: Axele.Giroud@manchester.ac.uk

Journal of International Business Policy (2020) 3, 465-468.

https://doi.org/| 0.1057/s422 |4-020-00078-2
}

This year's World Investment Report (WIR) marks its 30th anniversary edition. Over the past three decades, the report has established itself firmly as one of the leading sources for trends of global foreign direct investment (FDI), as well as focusing on thematic issues of relevance to the understanding of multinational enterprises' (MNEs) strategies, national and international investment policies, and sustainable development. This makes it an essential guide for international business academics and policymakers. UNCTAD's World Investment Report 2020 is pertinent, timely, and engages in forward looking thinking of relevance to developing and developed countries alike. The report presents the latest data on flows and stocks of foreign investment globally, and its thematic chapters focus on International Production Beyond the Pandemic, and on Investing in the Sustainable Development Goals (SDGs).

The report includes recent trends in global FDI flows for 2019 and early 2020 in Chapter 1 . It forecasts a significant downward trend of up to $40 \%$ in global FDI in 2020 - meaning FDI could decline to its lowest level since the mid-2000s. Future trends are uncertain, and will depend on the length of the global health crisis, the severity of the economic downturn, policies adopted by governments globally, the resilience of global value chains (GVCs), and firm's ability to restructure activities. The COVID-19 global health crisis adds to existing socio-economic and political factors that were already exerting pressures on global trade and FDI. Chapter 2 demonstrates that prospects vary by region. Developing countries are expected to experience a larger FDI decline than developed countries, mostly because of their greater dependence on investment in severely hit GVC-intensive and extractive industries, and because of the difficulties in implementing recovery measures. 
Recent changes in policies are presented in Chapter 3. In 2019, the majority of new policies implemented aimed at liberalizing investment (e.g. investment facilitation measures, liberalization of FDI in selected industries), and improving aftercare measures (incl. investment retention). But new restrictive policy measures were introduced, often in developed countries, such as more stringent screening regimes for foreign investment. A number of policies were also implemented during the global health crisis. For instance, some investment policies in healthcare aimed at increasing investment through new incentives (e.g. to enhance production in the health sector, increase healthrelated $R \& D)$, some measures aimed at protecting health care and other strategic industries (e.g., mandatory production, exports bans on medical equipment), and other measures addressed major supply chain disruptions, such as support for local SMEs (see Gereffi [2020] for a critical discussion on policy measures adopted to overcome shortages in medical supplies). On an international level, the crisis has affected treaty-making, with the cancelation or postponement of key negotiations for bilateral investment treaties or for treaties with investment provisions.

The introduction of a new thematic chapter, Chapter 5, focusing on the SDGs is a welcome addition to the WIR. The analysis shows that progress has been made. For instance, over 150 countries have adopted new national strategies or adapted existing plans to reflect the United Nations' SDGs. Investment in key sectors has risen (incl. infrastructure, climate change mitigation, food and agriculture, health, telecommunication, and ecosystems and biodiversity), but mostly in developed countries. Meeting the SDGs by 2030 will require more and a variety of financial resources (e.g. domestic, international, public and private), especially in developing countries and LDCs, whilst ensuring investment is carefully implemented. New guidance for sustainable finance and corporate governance, and efforts by securities regulators and policy makers (for instance through the UN Sustainable Stock Exchange initiative and the International Organization of Securities Commissions) can support organisations in the integration of good environmental, social and governance standards into their practices. Policy makers, at national and international levels, must also continue to mainstream SDGs into national investment policy frameworks and the International Investment Agreement regime.
The remainder of this review will focus on this year's main thematic chapter, Chapter 4 . Because this year marks the $30^{\text {th }}$ anniversary of the WIR, the chapter draws on previous reports that described shifts in FDI and GVC activities and in investment policy. The analysis also integrates the predicted impact of the current global health crisis to present possible future trends for the transformation of international production. International production is organised around investment and trade flows globally, which vary across three key dimensions, namely the degree of fragmentation and length of value chains; the geographical spread of value added; and governance choices of MNEs. Exploring future avenues for trade and FDI, the report considers industry and economic activity perspectives, and structures the discussion around three mutually reinforcing factors (e.g. technology, policy and the sustainability imperative).

First, the pace and extent of adoption of new technologies in the New Industrial Revolution impact international production to varying degrees. For instance, digitization can have positive impacts on countries' and companies' participation in GVCs (e.g., supporting inclusiveness by allowing suppliers in developing countries easier access to GVCs). But it can also have negative impacts (e.g., exacerbating the value-added gap between countries at different stages of the GVC development ladder, limiting upgrading and catching-up). Automation can increase the availability of cheaper industrial robots, lead to reshoring strategies, and lessen the role of smaller suppliers. 3D printing can reduce the labour component in production, and lead to less efficiency-seeking FDI.

Second, the policy environment is evolving. Governments develop new industrial policies to try and address new challenges arising from the technological revolution, GVC participation, and sustainability goals. Trade tensions are rising. New investment restrictions are introduced to ensure national security. Examples include policy measures in the areas of intellectual property, $R \& D$ and data protection to secure competitive advantage. Rising interventionism in national policies, protectionism towards trade and investment, and shifts from multilateral to regional and bilateral frameworks may lead to increased fragmentation in economic cooperation, and may affect the ease and cost of cross-border transactions. 
Third, sustainability concerns are rising and so is their influence on MNEs, trade and FDI. Sustainability concerns over Environmental, Social and Governance (ESG) issues (e.g., social impact, labour standards, gender equality) influence MNEs' behaviour and governance choices. Environmental concerns affect the degree of fragmentation and geographical distribution, for instance, as a result of climate change policies, emissions targets or green deals. Market-driven changes are also taking place, such as consumers' push for responsibly produced goods and services, new business opportunities created by climate change mitigation and adaptation, and rising pressures on companies to address climate risks from investors, banks, insurers and financial market regulators. Beyond policies and market-driven changes, climate change has a physical impact on international production.

The pressures mentioned above explain why we can expect a transformation of the international production system. The implications of such a transformation for countries must be better understood by academics and policymakers. For developing and emerging economies, the role of trade, investment and GVCs in economic development will likely change profoundly, meaning that their governments need to identify how to best design new policies for development. The report suggests four likely future trajectories of international production (WIR, 2020, p. 156), namely reshoring, diversification, regionalization, or replication. It is possible that a combination of all these will take place, and there are risks of a retreat in GVCs and declining cross-border investment. Yet, rapid changes may be detrimental, especially given current uncertainties around a post-pandemic recovery. As such, a gradual adjustment of international production networks to the new realities may be preferable. Policy action to make international production more sustainable while preserving the development benefits is, indeed, both necessary and urgent (WIR, 2020, p. 188).

Through the elaboration of this thematic chapter, UNCTAD contributes to the ongoing debate on the transformation of international production and the new investment-development path. Several issues deserve greater attention in academic research, and international business scholars are uniquely positioned to contribute to this discussion. First, although FDI and GVCs are closely linked, they are the result of distinct strategies by firms. International business scholars distinguish between locational, entry mode and value chain strategies. This is key in presenting novel methodological approaches to account for firm heterogeneity (Fortanier et al., 2020), and to help uncover the impact of various value chain configurations and governance mechanisms on the upgrading or downgrading trajectories for firms (Kano et al., 2020), on both the formal and the informal sector (Narula, 2019), as well as on host countries' economic development. More research on how these will evolve as a response to the current health crisis and to existing technological and sustainability challenges is needed. Second, the sustainability implications of shifting international production must be carefully assessed. Shifts in international trade and investment have both positive and negative consequences, and the impact differs along various sustainability perspectives. How will we ensure adherence to the SDGs in a world of uncertainty? Third, the policy implications of the transformation in international production must be explored, particularly from the standpoint of the SDGs. Here, what is needed is a much deeper integration of political forces in IB research (e.g., see Witt, 2019). More consideration should also be given to the least developed countries, because they face higher uncertainty in their paths to development. Which sustainable development strategies should countries adopt in times of uncertainty? Providing answers to the questions above is a challenging but important task.

Policy makers need advice to attract the right type of investment, promote sustainable value chain activities, and foster institutional environments that support their development agenda. UNCTAD and the WIR team are uniquely placed to leverage academic knowledge, integrate state-ofthe-art research into the formulation of new policy agendas, and provide sound policy advice to developing country governments, notably through technical assistance programmes. International Business scholars can contribute to these debates by engaging with this journal - Journal of International Business Policy - and promote greater evidenced-based policy making. Good illustrations include the forthcoming special issues on the SDGs, on Global Value Chains, and the current series emphasizing IB scholars' views on the impact of the global health crisis on future trends on global investment and trade (Van Assche \& Lundan, 2020). As such, the mutually beneficial relationship between IB scholars and UNCTAD means research will continue to inform policy and practice. 


\section{REFERENCES}

Fortanier, F., Miao, G., Kolk, A., \& Pisani, N. 2020. Accounting for firm heterogeneity in global value chains. Journal of International Business Studies, 51(3): 432-453.

Gereffi, G. 2020. What does the COVID-19 pandemic teach us about global value chains? The case of medical supplies. Journal of International Business Policy, 3(3): 287-301.

Kano, L., Tsang, E. W., \& Yeung, H. W. C. 2020. Global value chains: A review of the multi-disciplinary literature. Journal of International Business Studies, 51(4): 577-622.

Narula, R. 2019. Enforcing higher labor standards within developing country value chains: Consequences for MNEs and informal actors in a dual economy. Journal of International Business Studies, 50(9): 1622-1635.
Van Assche, A., \& Lundan, S. 2020. COVID-19 and international business policy. Journal of International Business Policy, 3(3): 273-279.

Witt, M. A. 2019. De-Globalization: Theories, predictions, and opportunities for international business research. Journal of International Business Studies, 50(7): 1053-1077.

WIR. 2020. World Investment Report 2020: International production beyond the pandemic. Geneva: United Nations Conference on Trade and Development.

Publisher's Note Springer Nature remains neutral with regard to jurisdictional claims in published maps and institutional affiliations. 